Marian Szarmach ${ }^{*}$

\section{Zbyt duży to był ciężar jak na moje siły}

DOI: http://dx.doi.org/10.12775/LC.2018.062

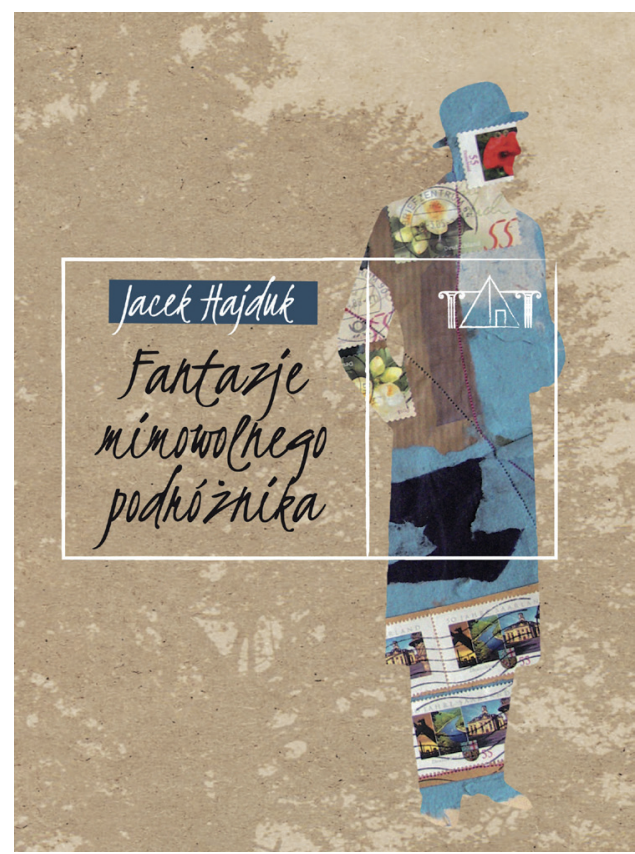

\section{P}

od koniec 2016 roku ukazała się publikacja Jacka Hajduka Fantazje mimowolnego podróżnika, poświęcona nienapisanej książce emigracyjnego autora Jerzego Stempowskiego o Owidiuszu wygnańcu ${ }^{1}$.

\footnotetext{
* Emerytowany profesor Uniwersytetu Mikołaja Kopernika w Toruniu. Zainteresowania badawcze: tragedia grecka, cesarska literatura grecko-rzymska, autorzy Drugiej Sofistyki i wczesnochrześcijańscy. E-mail:marszar@umk.pl.

1 Hajduk, Jacek (2016). Fantazje mimowolnego podróżnika. Wojnowice-Wrocław: Kolegium Europy Wschodniej im. Jana Nowaka-Jeziorańskiego. Odwołania do recenzowanego tomu lokalizuję przez wskazanie w nawiasie numeru strony.
}

Jacek Hajduk (rocznik 1982), filolog klasyczny i polonista, jest zatrudniony w Instytucie Filologii Klasycznej Uniwersytetu Jagiellońskiego. Poza pracami stricte naukowymi, jak chociażby doktorat o antyku $\mathrm{w}$ polskiej powieści historycznej w XX wieku na przykładzie twórczości Hanny Malewskiej i Teodora Parnickiego, wydał też nowy przekład wierszy Konstandinosa Kawafisa i powieść o Pliniuszu Młodszym.

Jerzy Stempowski, pochodzący z Ukrainy, odebrał gruntowną edukację humanistyczną w gimnazjach Warszawy i Krakowa, którą pogłębil, studiując w Monachium oraz Zurychu medycynę, a także historię. Był synem Stanisława, mistrza polskiej masonerii, wieloletniego towarzysza życia Marii Dąbrowskiej. Stempowski junior w okresie międzywojennym pracował w Ministerstwie Spraw Zagranicznych i zajmował się dziennikarstwem. Po wojnie osiadł w Szwajcarii. Pisał głównie eseje, które wydawał w Paryżu i Londynie. Przygotowanie klasyczne dało jemu i ludziom jego generacji szerokość horyzontu intelektualnego i pogłębiło ich wyobraźnię. Ze smutkiem stwierdził, że wszystko to zmieniło się po wojnie, kiedy „nawet literaci przestali czytać wiersze łacińskie", bo zachwyciła ich Françoise Sagan (s. 117, Hajduk cytuje esej O pewnej tradycji klasycznej).

W roku 1955 pisze do mieszkającej również w Szwajcarii Krystyny Marek, absolwentki UJ, profesora prawa międzynarodowego w Genewie, że w związku z przypadającym niebawem anno Ovidiano (2000. rocznica urodzin Owidiusza w roku 1958) planuje przygotować książkę o poecie, co będzie wymagało podjęcia odpowiednich studiów. W roku 1961 poinformowal Dąbrowską, że zebrał do niej spory materiał. Będzie pracował nad nią w najbliższym czasie. W tym celu wybiera się nawet do 
Sulmony, by poznać bliżej miasto, z którego Owidiusz pochodził, a także do Neapolu, by $\mathrm{w}$ tamtejszym narodowym Museo Archeologico studiować freski pompejańskie dające pojęcie o estetyce I i II wieku. Czynił to z Obrazami Filostratosa w ręku, podstawowym tekstem objaśniającym antyczne malarstwo. Polski tłumacz tego utworu, ks. Remigiusz Popowski, napisal, że uwagi te zmuszają widza do kontemplacji, skłaniając go do pogłębionych przeżyć artystycznych (Filostrat Starszy 2004: 40).

W liście z lutego 1956 roku do Jerzego Giedroycia Stempowski donosi, że może otrzyma na napisanie tej książki skromne stypendium amerykańskie. Pisze, że zbliżające się za dwa lata uroczystości owidiańskie odnowią zapewne związki Polaków z łaciną i klasyczną tradycją. Jego książka miałaby liczyć 120-150 stron. Nie będzie to rozprawa z dziedziny filologii klasycznej, lecz raczej próba krytyki literackiej. Składać się będą na nią szkice o poecie, o jego ojczyźnie, czyli Sulmonie, o sławie, jaką cieszył się w Europie Wschodniej, i o jego wygnaniu. Humorystycznie brzmią jednak rozterki Stempowskiego, w jakim języku miałby tę książkę napisać - po włosku, niemiecku czy polsku. W żadnym wypadku po francusku, gdyż francuscy latyniści nie dopuszczają w ogóle nowej myśli, pozostając autorami „przeważnie głupich i banalnych sądów” o poecie (s. 43).

W paryskiej „Kulturze” (1958) Stempowski opublikował esej o Sulmonie, który Hajduk traktuje jako przymiarkę do książki o rzymskim poecie. Za Jackiem Bocheńskim uważa, że doszły w nim do głosu słowiańszczyzna, zarośla $\mathrm{w}$ ukraińskich jarach, nostalgia i Dniestr (s. 161 i dalej). Krajobraz Sulmony jawi się Stempowskiemu jako wspomnienie młodości. Autora dopada chyba też zwątpienie, czy pisanie książki o Owidiuszu ma jednak w ogóle sens. Mimo tych wahań Stempowski nawiązuje kore- spondencję z Lidią Winniczuk, profesorem Uniwersytetu Warszawskiego i redaktorką „Meandra”, w którym całe moje pokolenie badaczy starożytności debiutowało i publikowało. W swoich pracach przeciwstawiała się ona lekceważeniu wygnańczej poezji Owidiusza, co powinno przypaść do gustu Stempowskiemu, jeśli do nich dotarł. W roku 1958 pisze jej o jubileuszu owidiańskim celebrowanym w Sulmonie, zaznaczając uszczypliwie, że łacińskie barokowe zaproszenie na nie wyszło spod pióra samego profesora Ettore Paratore, który na tej uroczystości popisywał się pustosłowiem. Zdziwił mnie ten osąd, gdyż Paratore należał do wybitnych włoskich latynistów, co podkreślali podczas moich studiów toruńscy profesorowie. Wręcz z estymą sięgam niejednokrotnie do wydanych przez niego z włoskim przekładem i komentarzem tekstów łacińskich, jak tragedie Seneki, którą to książkę mam we własnej bibliotece. Stempowski pisze dalej o sarmackiej przynależności Owidiusza, jak to jest w Rzeczy o wolności stowa Norwida (fragment IX). Poeta jawi się mu nie tylko archetypicznym wygnańcem, ale też ziarnem, z którego wyrasta nowa zupełnie kultura, nasza, polska, wschodnioeuropejska (s. 148). Chyba nie przytaknęłaby temu pani profesor. Jej korespondenta zdziwiła też nieobecność polskiej uczonej na konferencji w Sulmonie, mimo że figurowała na liście zaproszonych. Po prostu nie dostała na czas paszportu, co go zapewne zaskoczyło, jak dziwiło Ignacego Wieniewskiego wiele innych spraw, kiedy spotkała się z nim w roku 1983 w Londynie.

Stempowski wymieniał listy o swojej książce o Owidiuszu również ze Stanisławem Vincenzem. Z nim czytał kiedyś po grecku Argonautyki Apolloniosa Rodyjskiego, hellenistyczny epos, którego przekład Emilii Zybert ukazał się niedawno (2012). W tej poczcie dochodzi też do głosu pasja botaniczna Stempowskiego, 
któremu Owidiusz jawi się „poetą drzew”, zwłaszcza w Metamorfozach. Wśród przyrodniczych uwag znajduje się wiele reminescencji „Z jego życia starego, sprzed momentu udania się na emigrację" (s. 110). Stempowski deklaruje się też dumnie jako sceptyk - wolterianin afirmujący rozum, tolerujący jednak idee religijne.

Giedroyciowi, indagującemu go kilkakrotnie, co z Owidiuszem, odpowiada w maju 1963 roku, że z powodu innych zajęć nie może napisać tej książki. Chciałby może powiedzieć słowami Owidiusza: Maius erat nostris viribus illud onus („Zbyt duży to był ciężar, jak na moje siły" - Owidiusz, Żale, IV 10 w. 36, przekład Jacka Hajduka). Czyż wers Gałczyńskiego z Notatek z nieudanych rekolekcji paryskich: „za duży wiatr na moją wełnę" nie jest aluzją do słów rzymskiego poety?

Śmierć Stempowskiego w Bernie w 1969 roku zakończyła jego kontakty z kulturą antyczną i umiłowanym Owidiuszem.

Hajduk poświęcił $\mathrm{w}$ tej książce osobny rozdział emigracyjnym tłumaczom Homera, pisząc, że „nie ma dla tłumacza szczytu wyższego i trudniejszego niż epopeja narodowa, a już szczególnie taka, do której słusznie zgłaszają pretensje wszyscy. W naszym kręgu kulturowym są trzy takie dzieła - Iliada i Odyseja Homera oraz Wergiliuszowa Eneida" (s. 127).

W wieku XX powstało kilka ich polskich tłumaczeń, wśród nich na emigracji Iliada Ignacego Wieniewskiego (Londyn 1961), Odyseja Józefa Wittlina (Londyn 1957) oraz Eneida Wieniewskiego (Londyn 1971). Nie mogę zgodzić się z Hajdukiem, że obaj zostali skazani w Polsce na niebyt. Oba przekłady Wieniewskiego wydano również w kraju (w 1973 i 1984). Doszło nawet do paradoksalnej sytuacji, że rozmaite redakcje zaczęły domagać się cytowania Iliady i Eneidy w trudno w kraju dostępnych przekładach sprzedawanych niemal „spod lady”. Spotkaty się też one z uznaniem recenzentów, wśród których należy przede wszystkim wymienić szczegółowe analizy prof. Zofii Abramowiczówny, tłumaczki Bukolik i Georgik Wergiliusza w serii Biblioteki Narodowej Ossolineum (1953). Omówienie wydanej w Londynie „polskiej” Iliady kończy ona życzeniem, by „Tłumacz dał nam z czasem równie wierną i poetyczną Odyseję" (Abramowiczówna 1964: 374). W książce Hajduka został również poruszony temat przykrych, emigracyjnych swarów, jakie przekłady te wywołały. Wittlin pisał wówczas, że starano się wygrywać „Iliadę Wieniewskiego przeciw mojej Odysei. Wygląda to na jakąś zorganizowaną akcję od samego początku” (za Hajdukiem, s. 129).

Autor dodał jeszcze do książki niejako appendix: Owidiusz po Stempowskim, gdzie pisze o obszernej monografii prof. Stanisława Stabryły o poecie, wydanej w Ossolineum w 1989 roku, którą opiniowała do druku Winniczuk. Stabryła dokończył też dla Biblioteki Narodowej (od IX księgi) przekład Metamorfoz Owidiusza rozpoczęty przez filologa klasycznego i poetkę Annę Kamieńską, zmarłą w 1986 roku. Tom z jego wstępem i komentarzem zastąpił w roku 1995 wcześniejszą edycję eposu Owidiusza w tej serii z roku 1953, zawierającą tłumaczenie Brunona Kicińskiego $\mathrm{z}$ pierwszej połowy poprzedniego stulecia. Szkoda, że Autor nie wymienił tu obszernej pracy prof. Andrzeja Wójcika Owidiusz poezje znad Morza Czarnego (Wójcik 2003), a także artykułu prof. Barbary Milewskiej-Waźbińskiej Exulowie wszystkich czasów, czyli Owidiusz i inni (MilewskaWaźbińska 2008), w którym został porównany nonkonformizm polityczny Jacka Kaczmarskiego, widoczny w jego wierszu Starość Owidiusza, z emigracyjnymi wyznaniami poety z Sulmony.

Omawiana książka wymagała od jej Autora nie tylko gruntownej znajomości 
twórczości Owidiusza i stosownej literatury przedmiotu, ale i wielu kwerend w polskich i zagranicznych bibliotekach oraz archiwach (Rapperswil). Wykonał swoje zadanie wzorowo. Otrzymaliśmy publikację o intymnych kontaktach z kulturą klasyczną przedstawiciela pokolenia, dla którego była ona istotnym pokarmem umysłu. „Nie ma kultury bez tradycji i nie ma życia kulturalnego jednostki bez uświadomienia sobie i zrozumienia tej tradycji” - pisał rówieśnik Stempowskiego, prof. Stefan Srebrny (1936: 7).

\section{Bibliografia}

Abramowiczówna, Zofia 1964. „Iliada”. Eos 54: 367-374.
Filostrat Starszy 2004. Obrazy. Tłum., wstępem, komentarzem i przypisami opatrzył Remigiusz Popowski. Warszawa: Prószyński i S-ka.

Hajduk, Jacek (2016). Fantazje mimowolnego podróżnika. Wojnowice-Wrocław: Kolegium Europy Wschodniej im. Jana Nowaka-Jeziorańskiego.

Wójcik, Andrzej 2003. Owidiusz - poezje znad Morza Czarnego. Wybór Żalów i Listów znad Morza Czarnego w przekł. Elżbiety Wesołowskiej. Poznań: Ars Nova.

Milewska-Waźbińska, Barbara 2008. „Exulowie wszystkich czasów, czyli Owidiusz i inni”. Symbolae Philologorum Posnaniensium Graecae et Latinae 18: 421$-427$.

Srebrny, Stefan 1936. Co zawdzięczamy kulturze świata antycznego. Wilno: „Filomata”. 